\title{
KONDISI SUMUR DAN PEMODELAN ARAH ALIRAN AIRTANAH BEBAS PADA BENTUKLAHAN FLUVIOMARIN DI JAKARTA
}

\author{
Cahyadi Setiawan'), Suratman2), Muh Aris Marfa,i2) \\ 1)Mahasiswa Prodi S3 Geografi UGM \\ 2)Dosen Fakultas Geografi UGM \\ Email : cahyadiunj@yahoo.com
}

\begin{abstract}
Growing population have an impact on the strategy of fulfillment the water need and degradation of groundwater quality in Jakarta, especially in fluviomarine landforms in Jakarta. The purpose of this study was to determine the condition of wells and create a model of groundwater flow direction on fluviomarine landforms based on the season. Methods in this research study include three main aspects, namely population, characteristics of the object under study, and analysis. The population in this study using 30 groundwater wells sample representative of the population. Relating to the characteristics of the object under study, this study using a survey method. The survey is a sample survey on wells population who still use unconfined groundwater. About data analysis, then in this study used quantitative and qualitative approaches to the modeling of the groundwater flow direction using the Inverse Distance Weighted (IDW) in ArcGIS.

The results showed that the unconfined groundwater wells in the study area consisted of dug wells and pantek wells. It is generally known that groundwater levels in the rainy season are higher than the dry season with a depth of groundwater level in the dry season to be deeper than the rainy season. Most of the groundwater level in organic settlements in the study area is below sea level, whereas in planned settlements is rarely found people who use groundwater. The depth of unconfined groundwater well less than $20 \mathrm{~m}$ with a thickness of water on the wells in the rainy season are thicker than the dry season. Groundwater flow direction along the north coast of central and western parts likely to lead to the mainland, while the southern part has a groundwater flow that is likely to lead to the North.
\end{abstract}

\section{Keywords: Fluviomarine Landforms In Jakarta; Unconfined Groundwater; Groundwater Flow Direction}

\section{PENDAHULUAN}

Letak Jakarta yang berada di tepi pantai dengan laut yang dapat dilayari, dan hinterland yang relatif tidak menyajikan hambatan-hambatan fisikal yang berarti. Konsekuensi keruangan yang muncul adalah adanya kesempatan berkembang secara spasial ke segala arah yang seimbang, namun karena adanya pembatas tubuh perairan yang berupa teluk di bagian utara maka pada bagian tersebut jelas akan terganggu sehingga perkembangan horizontal sentrifugal akan terhenti. Ekspresi keruangan yang seharusnya berbentuk bulat ideal terpotong pada bagian ini sehingga akan terbentuk sebuah ekspresi spasial seperti kipas (Yunus, 2005).

Menurut Gunawan (2010), bahwa $40 \%$ wilayah Jakarta berada di bawah permukaan air laut dan berbentuk rawa pantai sehingga sangat memungkinkan untuk terjadinya banjir. Pemanfaatan 
ruang kota dengan pembangunan fisik dan peningkatan jumlah penduduk yang signifikan juga dapat mempengaruhi periode ulang wilayah yang dilanda banjir. Lahan yang topografinya sebenarnya tidak cocok untuk menjadi wilayah terbangun dan ditetapkan sebagai lahan basah yang digunakan untuk menampung air sewaktu banjir sejak tahun 1960 kini telah dibangun untuk berbagai keperluan kota. Sistem kanal tidak berhasil karena topografi Jakarta yang datar sehingga air tidak dapat mengalir secara gravitasi. Adanya sedimentasi lumpur juga menyebabkan aliran air menjadi tidak lancar, sehingga pembangunaan kanal hanya bersifat menanggulangi banjir secara sesaat.

Bentuklahan fluviomarin terbentuk oleh gabungan dari proses fluvial dan marin. Bentuklahan fluviomarin merupakan suatu morfologi permukaan Bumi yang genetikanya sangat di kontrol oleh adanya tenaga eksogen (Collins English Dictionary, 2003). Menurut Noor (2014), bahwa tenaga eksogen adalah tenaga yang berasal dari luar Bumi seperti sinar Matahari dan gaya tarik gravitasi yang menghasilkan berbagai macam proses seperti penguapan, hujan, angin, dan gelombang laut. Tenaga eksogen juga dikenal sebagai tenaga destruksional (destructional) karena mengubah bentuk muka bumi dengan cara pelapukan, erosi (mass wasting) dan sedimentasi. Pada bentuklahan fluviomarin proses eksogen yang sangat mendominasi adalah proses fluvial dan proses marin. Bentuklahan fluviomarin di Jakarta terletak di bagian Utara Jakarta.

Verstappen (2013) mengatakan bahwa perkembangan dataran rendah Jakarta telah terjadi 5.000 tahun yang lalu. Angka tersebut dihitung berdasarkan kecepatan pengendapan lumpur di tepi pantai dan berdasarkan stratigrafi dari dataran kipas yang berasal dari zaman Holosen Tua dan Tengah. Dataran aluvial pantai merupakan daerah yang mempunyai struktur horizontal, dan terjadi karena hasil pengendapan material di pantai laut.

Dataran Jakarta secara geomorfologi digolongkan ke dalam dataran aluvial pantai dan sungai. Wilayah Jakarta mempunyai bentang alam datar, sungai bermeander, yang sebelumnya merupakan daerah dataran rawa, baik rawa pantai, laguna, ataupun rawa belakang akibat limpasan yang melampaui tanggul alam. Dataran rendah aluvial Jakarta memiliki sistem perairan yang berarah radial seperti kipas sebagai ciri dari perairan gunung api muda. Dataran aluvial sekitar Teluk Jakarta dipengaruhi oleh perubahan berulangkali dari muara Sungai Cisadane dan Citarum dan oleh pembentukan beting gisik yang selangseling (intermittent) disebabkan oleh periode dari angin di pantai di atas ratarata yang menyertai pergantian penurunan muka air laut. Kondisi tersebut mengakibatkan Jakarta rawan terhadap banjir dan penggenangan.

Sebagian besar penduduk perkotaan mengambil air untuk kebutuhan sehari-hari dari air tanah bebas dengan membuat sumur yang dapat berbentuk sumur gali atau sumur pantek, air PAM dan air tanah dalam (sumur bor). Penggunaan airtanah akan terus berkembang dan meningkat sejalan dengan perkembangan perkotaan. Seiring dengan perkembangan perkotaan tersebut, maka permasalahan air juga meningkat baik dari segi kuantitas maupun kualitasnya. Apabila ditinjau dari segi kuantitas air tanah terjadi penurunan muka air tanah 
dan cadangan air tanah, sedangkan dari segi kualitas air tanah terjadi perubahan kualitas air dan penyusupan air bergaram ke daratan di daerah pantai. Oleh karena itu, penggunaan air tanah secara berlebihan di perkotaan akan menyebabkan masalah ketersediaan air, kerusakan tanah, kerusakan lingkungan dan pencemaran. (Martopo, 1984; Sudarmadji, 1991).

Bertambahnya jumlah penduduk berdampak juga terhadap strategi pemenuhan kebutuhan air bersih masyarakat serta penurunan kualitas air tanah di Jakarta. Berdasarkan penelitian pada tahun 2010 diketahui bahwa selain penyusutan sumber air tanah, masyarakat juga menghadapi masalah pencemaran air baku. Bahkan di DKI Jakarta instrusi air laut sudah sampai Jalan Jenderal Sudirman, Jakarta Pusat (Setiawan et.al. 2010).

Penelitian pada tahun berikutnya diketahui bahwa terjadi penurunan kualitas air tanah yang signifikan di sepanjang pesisir Jakarta. Hal ini dipengaruhi oleh banjir rob dan juga aktivitas masyarakat di sekitarnya. Berdasarkan total penggunaan air tanah yang digunakan oleh masyarakat Jakarta dan volume air tanah yang dapat dilepas mengindikasikan terjadinya defisit air tanah. Hal ini menyebabkan terjadinya kekosongan air pada pori-pori tanah sehingga berdampak pada penurunan tanah (land subsidence) yang berlangsung secara terus menerus di DKI Jakarta (Setiawan et.al. 2011).

Begitu pula penelitian yang pernah dilakukan oleh Marfai dan juga Aert (Marfai et.al. 2009 dan Aert et.al. 2009) menunjukan bahwa genangan di Jakarta merupakan bencana utama yang menyebabkan kerugian harta, benda dan jiwa. Hal ini khususnya terjadi pada daerah cekungan, dataran aluvial dan lingkungan pantai.

Berdasarkan

lingkungan pada lokasi penelitian tersebut, maka dirasa perlu untuk mengetahui kondisi sumur dan memodelkan arah aliran air tanah bebas pada bentuk lahan Fluviomarin berdasarkan musim untuk mengetahui gambaran tinggi muka air dan pergerakan air tanah serta kemungkinan arah terjadinya pencemaran.

\section{METODOLOGI PENELITIAN}

Metode pada penelitian ini mencakup tiga aspek utama penelitian, yaitu: 1) berkaitan dengan populasi, 2) berkaitan dengan karakteristik objek yang diteliti, dan 3) berkaitan dengan analisis. Ketiganya dapat digambarkan menjadi segitiga metode penelitian seperti pada Gambar 1.

Secara diagramatis, Gambar 1. di bawah ini menggambarkan keterkaitan antara metode penelitian yang terdiri dari populasi, karakteristik obyek, dan analisis. Berkaitan dengan populasi, maka pada penelitian ini menggunakan sampel yang dianggap mampu mewakili populasi.

Populasi yang dimaksud adalah seluruh sumur air tanah bebas pada bentuk lahan fluviomarin, dengan sampel sebanyak 30 sumur. Berkaitan dengan karakteristik obyek yang diteliti yaitu ai rtanah bebas, maka pada penelitian ini menggunakan metode survei. Survei yang dimaksud adalah survei sampel pada sumur-sumur penduduk yang masih menggunakan air tanah bebas. Berkaitan dengan analisis data, maka pada penelitian ini menggunakan pendekatan kuantitatif dan kualitatif dengan pemodelan arah aliran ai rtanah menggunakan Inverse Distance Weighted (IDW) pada ArcGIS. 


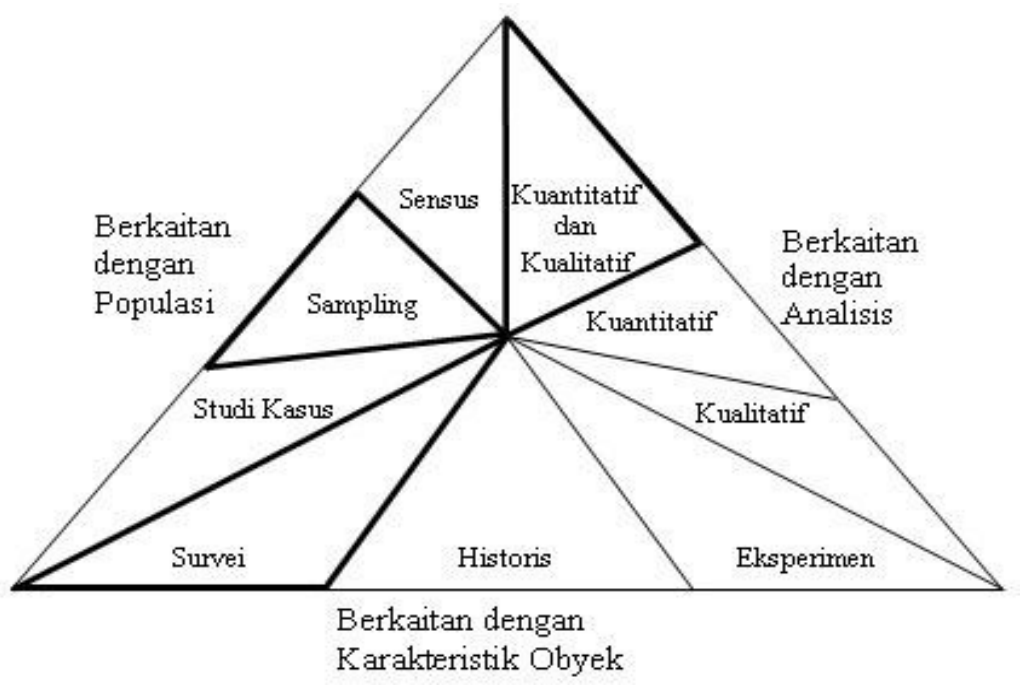

Gambar 1. Segitiga Metode Penelitian (dimodifikasi dari Yunus, 2010)

HASIL DAN PEMBAHASAN

1. Kondisi Sumur

Kondisi sumur ini terdiri dari diameter sumur, tinggi tempat dan tinggi muka air sumur, kedalaman sumur, kedalaman muka air tanah, dan ketebalan air sumur.

Diameter sumur diukur dan ditentukan berdasarkan lingkar dalam sumur ataupun ukuran diameter paralon yang dipergunakan. Diameter sumur gali biasanya sesuai dengan ukuran buis beton yang dipergunakan, yaitu ukuran
$70 \mathrm{~cm}$ hingga $120 \mathrm{~cm}$ dengan ketebalan $5 \mathrm{~cm}$, sedangkan sumur pantek menggunakan paralon berukuran 4 inch $(10,16 \mathrm{~cm})$. Diameter sumur ini dapat dijadikan dasar untuk menentukan volume air dalam sumur. Pada permukiman organis yang masih memanfaatkan air tanah lebih banyak ditemukan sumur gali dengan diameter $80 \mathrm{~cm}$, sedangkan pada permukiman terencana yang masih memanfaatkan air tanah banyak menggunakan sumur pantek dengan paralon berukuran 4 inch.

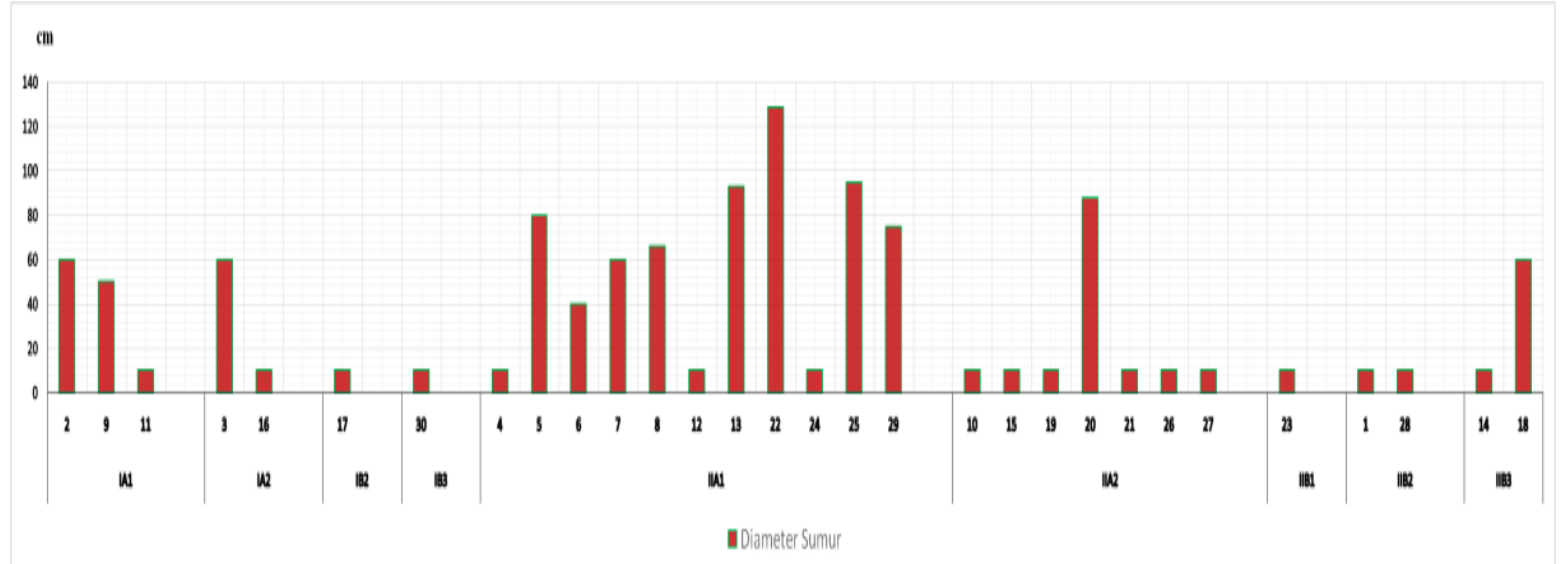

Gambar 2. Grafik Diameter Sumur di Daerah Penelitian 
Selanjutnya, untuk tinggi tempat diketahui dengan pengukuran langsung dan membandingkannya dengan data Digital Elevation Model (DEM). Pengukuran tinggi muka air sumur di daerah penelitian dilakukan dengan mengukur tinggi muka pada sumur air tanah bebas. Secara umum diketahui bahwa tinggi muka air tanah pada musim hujan lebih tinggi daripada musim kemarau. Sebagian besar tinggi muka air tanah pada permukiman organis di daerah penelitian berada dibawah muka air laut, sedangkan pada permukiman terencana sudah jarang dijumpai penduduk yang memanfaatkan air tanah. Hal ini menunjukkan bahwa pada permukiman organis masih banyak memanfaatkan air tanah untuk berbagai keperluan. Penurapan air tanah yang dilakukan tidak sebanding dengan suplai air tanah sehingga muka air tanah berada di bawah muka air laut.

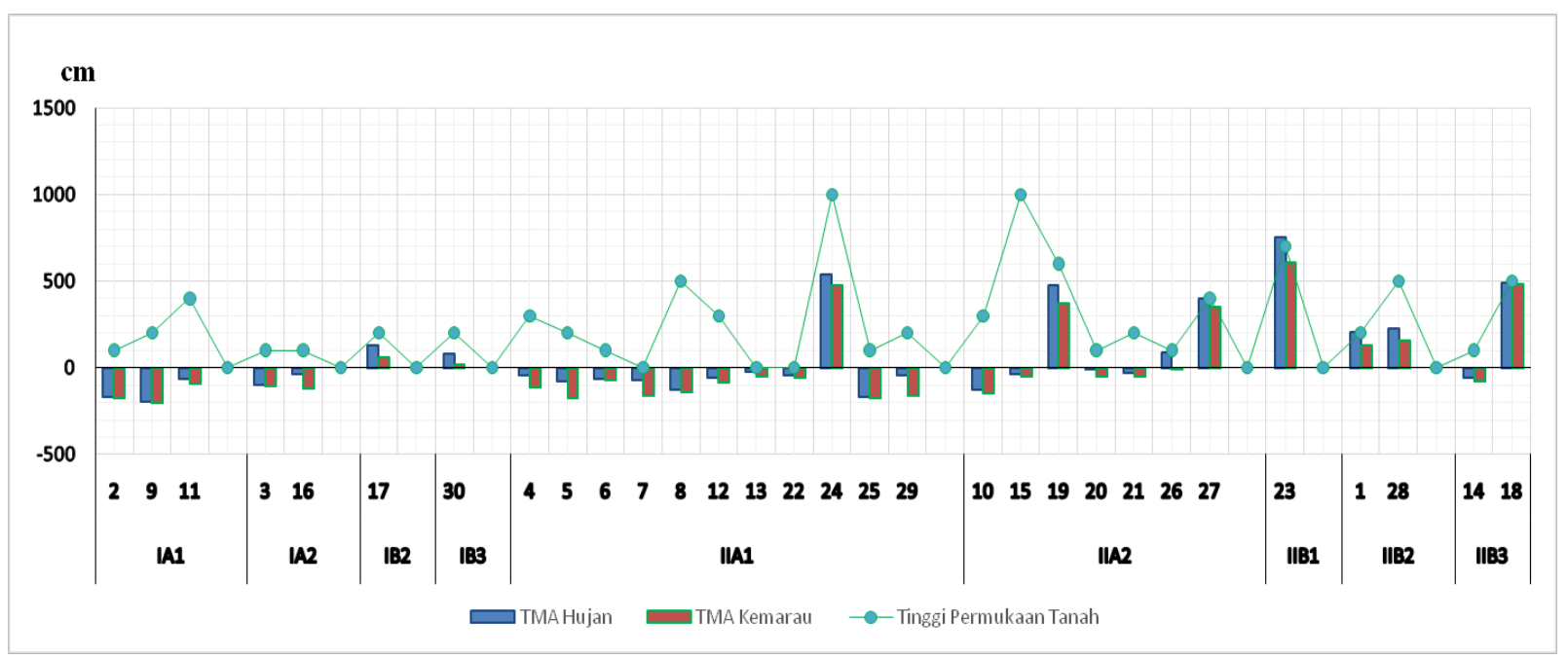

Gambar 3. Grafik Tinggi Tempat dan Tinggi Muka Air tanah di Daerah Penelitian

Pada pengukuran kedalaman air tanah bebas di daerah penelitian kurang dari $20 \mathrm{~m}$. Kedalaman sumur diukur dari permukaan tanah hingga dasar sumur. Pengukuran kedalaman sumur pada sumur gali dapat dilakukan dengan pengukuran langsung dengan meteran, sedangkan untuk sumur pantek kedalaman sumur diketahui dengan menanyakan jumlah paralon yang digunakan. Sumur pantek lebih banyak dijumpai di daerah penelitian baik pada permukiman organis maupun terencana dengan ukuran yang lebih dalam. Sumur gali lebih banyak dijumpai pada permukiman organis dengan kedalaman yang lebih dangkal dan merupakan sumur yang relatif sudah lebih lama digunakan oleh penduduk untuk memenuhi kebutuhan air rumah tangga. 


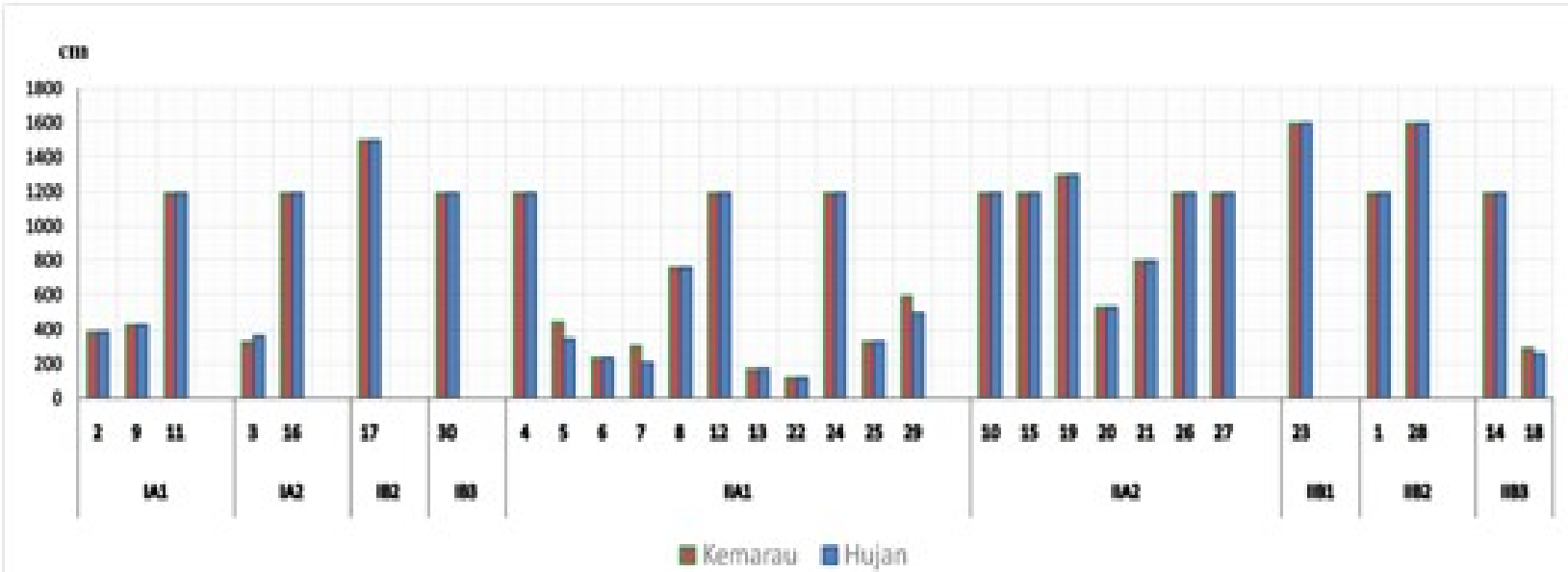

Gambar 4. Grafik Kedalaman Sumur Pada Musim Kemarau dan Hujan di Daerah Penelitian

Pada lokasi penelitian, muka air tanah (phreatic surface) ialah bidang datar yang menunjukkan permukaan air yang bertekanan sama dengan tekanan udara luar (1 atm), yang terlihat sebagai muka air pada sumur yang menembus akuifer bebas dan yang menunjukkan kesamaan potensial (Todd, 1980). Kedalaman muka air tanah dihitung dari muka tanah hingga muka air tanah. Poripori tanah di atas muka air tanah dapat menyimpan air dan sekaligus dapat sebagai filter alami terhadap polutan yang terbawa oleh aliran air sebelum air mencapai muka air tanah. Secara umum kedalaman muka air tanah pada musim kemarau lebih dalam dari musim hujan. Kedalaman muka air tanah pada musim kemarau minimum $20,00 \mathrm{~cm}$, maksimum $10,47 \mathrm{~m}$ dengan rata-rata $2,62 \mathrm{~m}$, sedangkan pada musim hujan minimum $3,27 \mathrm{~cm}$, maksimum $10,37 \mathrm{~m}$ dengan rata-rata $2,20 \mathrm{~m}$. Hal ini menunjukkan bahwa cadangan air tanah pada musim hujan lebih banyak dari musim kemarau karena adanya penambahan volume cadangan air tanah dari air hujan.

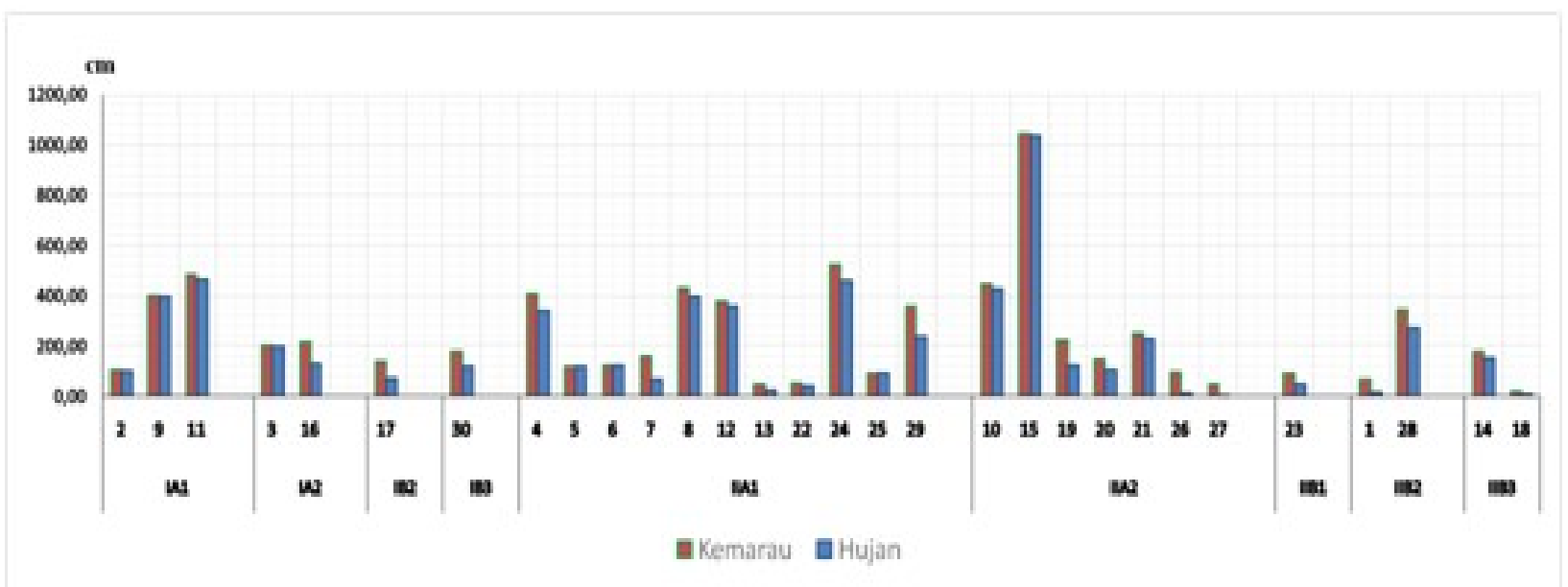

Gambar 5. Grafik Kedalaman Muka Airtanah Pada Musim Kemarau dan Hujan di Daerah Penelitian 
Terkait ketebalan air sumur dihitung dari permukaan air hingga ke dasar sumur di lokasi penelitian, relatif lebih tebal jika dibanding dengan ketebalan air pada sumur gali. Ketebalan air sumur pada permukiman organis sangat padat relatif lebih tipis jika dibanding pada permukiman yang lainnya. Hal ini karena semua sumur di permukiman organis sangat padat merupakan sumur gali. Pada permukiman organis padat dan permukiman terencana yang memiliki sumur mulai banyak ditemukan sumur pantek dengan ketebalan air lebih dari 5 meter. Ketebalan air sumur penting untuk mendapatkan air yang lebih jernih, karena material tersuspensi pada air akan terendapkan di dasar sumur.

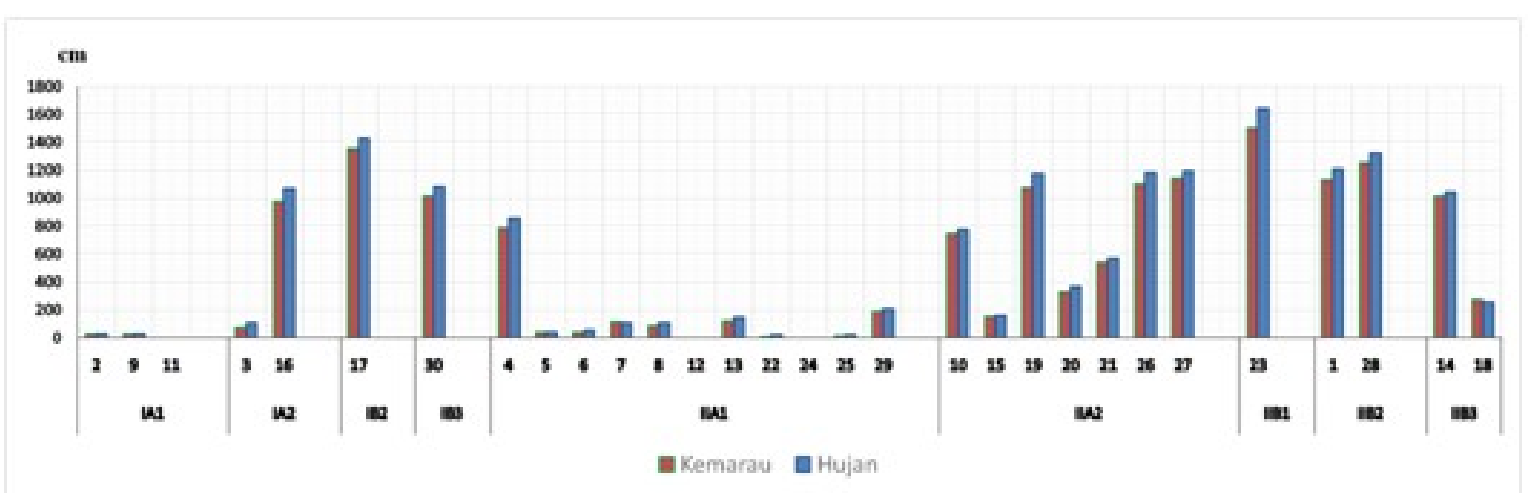

Gambar 6. Grafik Ketebalan Air Sumur Pada Musim Kemarau dan Hujan di Daerah Penelitian

\section{Model Arah Aliran}

Berdasarkan arah aliran air tanah pada musim kemarau dan hujan diketahui bahwa di sepanjang pantai utara bagian tengah dan barat memiliki aliran air tanah yang cenderung mengarah ke daratan, sedangkan pada bagian selatan memiliki aliran air tanah yang cenderung mengarah ke Utara. Hal ini berarti pada air tanah bebas pada bentuk lahan fluviomarin terjadi pertemuan air dari arah laut di sebelah utara dan dari arah darat di bagian selatan. Perbedaan tinggi muka air ini berkaitan dengan masih banyaknya penduduk yang masih memanfaatkan air tanah untuk memenuhi berbagai keperluan, seperti untuk mandi dan mencuci pakaian.

Berat jenis air laut sebesar 1,025 $\mathrm{kg} / \mathrm{m}^{3}$ lebih besar dari air tawar, yaitu sebesar $1,000 \mathrm{~kg} / \mathrm{m}^{3}$. Intrusi air laut berbentuk seperti baji yang berada di bawah air tawar ke arah darat. Pada bagian utara lokasi penelitian dominan mengalir ke arah darat yang berarti air laut masuk ke dalam air tanah bebas yang sesuai berat jenisnya berada di bawah air tawar, sedangkan air tawar yang berasal dari selatan berada di bagian atas dari air tanah bebas di daerah penelitian yang secara berangsur-angsur terus mengalami percampuran. Kondisi ini menyebabkan semakin dalam sumur dan semakin dekat sumur dari pantai cenderung memiliki Daya Hantar Listrik (DHL) yang semakin tinggi karena konsentrasi klorida (Cl) dalam air tanah yang semakin besar.

Sumber pencemar yang berasal dari arah darat oleh aktivitas manusia seperti coliform total dan bahan organik menunjukkan perbedaan konsentrasi yang nyata berdasarkan perbedaan tinggi tempat maupun tinggi muka air. 
Hal ini tentunya terkait dengan arah aliran air tanah yang mengarah pada tempat-tempat yang lebih rendah dan tingginya perubahan tutupan lahan yang tentunya berdampak pada semakin rendahnya kapasitas infiltrasi air ke dalam tanah mekipun sudah didukung dengan adanya program lubang resapan biopori.

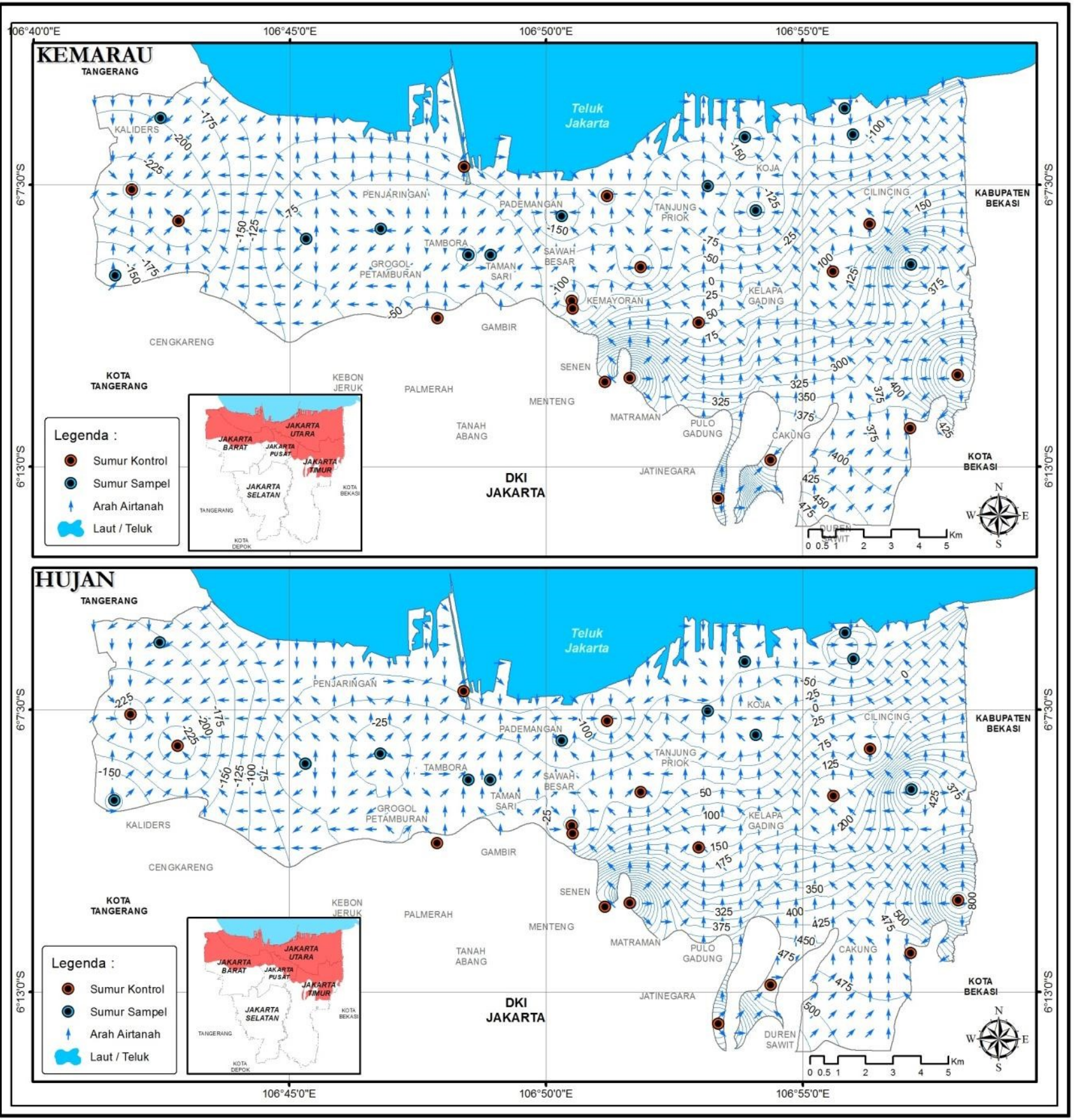

Gambar 7. Peta Arah Aliran Airt anah Bebas di Daerah Penelitian 


\section{KESIMPULAN}

Sumur air tanah bebas di daerah penelitian terdiri dari sumur gali dan sumur pantek. Secara umum diketahui bahwa tinggi muka air tanah pada musim hujan lebih tinggi daripada musim kemarau dengan kedalaman muka air tanah pada musim kemarau lebih dalam dari musim hujan.

Sebagian besar tinggi muka air tanah pada permukiman organis di daerah penelitian berada dibawah muka air laut, sedangkan pada permukiman terencana sudah jarang dijumpai penduduk yang memanfaatkan air tanah. Kedalaman sumur air tanah bebas kurang dari $20 \mathrm{~m}$ dengan ketebalan air sumur pada musim hujan lebih tebal daripada musim kemarau.

Arah aliran air tanah di sepanjang pantai utara bagian tengah dan barat cenderung mengarah ke daratan, sedangkan pada bagian selatan memiliki aliran air tanah yang cenderung mengarah ke Utara.

\section{DAFTAR PUSTAKA}

Aerts, J., Bowman, M., Dircke, P., Major, D., dan Marfai, M.A., 2009, Connecting Delta Cities, About Global Coastal Cities and Future Chalanges, VU University Press, Amsterdam, The Netherlands.

Collins English Dictionary-Complete and Unabridged. 2003. Diplomacy. (www) Available from: http://www.collinsenglish.dictionary .org. (diakses 24/06/2015).

Gunawan, R., 2010, Gagalnya Sistem Kanal, Pengendalian Banjir dari Masa ke Masa, Kompas Media Nusantara, Jakarta.

Marfai, M.A., Yulianto, F., Hizbaron, D.R., Ward, P. and Aerts, J., 2009,
Preliminary Assessment and Modeling The Effects of Climate Change on Potential Coastal Flood Damage in Jakarta, Joint Research Report, Vree Univ Amsterdam and Gadjah Mada university.

Martopo, S., 1984, Ketersediaan dan Kebutuhan Air di Indonesia Menjelang Tahun 2000. Dalam Seminar Hidrologi Geologi Fakultas Geografi UGM, Yogyakarta.

Noor, Dj., 2014, Geologi Untuk Perencanaan, Edisi Pertama, Graha Ilmu, Yogyakarta.

Setiawan, C., Muzani, Parwata, 2010, Kajian Intrusi Air Laut pada Estuaria Kali Sunter Jakarta Utara Sebagai Upaya Konservasi Lahan Wilayah Pesisir, Laporan Hibah Bersaing, Lembaga Penelitian Universitas Negeri Jakarta.

Setiawan, C., Muzani, Parwata, 2011, Kajian Potensi Air Tanah Bebas untuk Kebutuhan Air Domestik di DKI Jakarta, Laporan Hibah Bersaing, Lembaga Penelitian Universitas Negeri Jakarta.

Sudarmadji, 1991, Agihan Geologi Sifat Kimiawi Air Tanah Bebas di Kotamadya Yogyakarta, Disertasi, Fakultas Geografi UGM, Yogyakarta.

Verstappen, H.Th., 2013, Garis Besar Geomorfologi Indonesia, Terjemahan oleh Sutikno, Gadjah Mada University Press, Yogyakarta.

Yunus, H.S., 2005, Klasifikasi Kota, Pustaka Pelajar, Yogyakarta. , 2010, Metode Penelitian

Wilayah Kontemporer, Pustaka Pelajar, Yogyakarta. 